E3S Web of Conferences 1, 35001 (2013)

DOI: $10.1051 / \mathrm{e} 3$ sconf/20130135001

(c) Owned by the authors, published by EDP Sciences, 2013

\title{
Heavy metal contamination of the terrestrial environment from long-range atmospheric transport: Evidence from 35 years of research in Norway
}

\author{
E. Steinnes
}

Department of Chemistry, Norwegian University of Science and Technology, NO-7491 Trondheim, Norway, eiliv.steinnes@chem.ntnu.no

\begin{abstract}
Over the last 35 years the temporal and spatial trends of heavy metal deposition have been followed at regular intervals all over Norway. From the extensive evidence available it is clear that airborne $\mathrm{Pb}, \mathrm{Zn}, \mathrm{Cd}, \mathrm{As}, \mathrm{Sb}, \mathrm{Sn}, \mathrm{Hg}$, and $\mathrm{V}$ have all been added in excessive amounts to the environment in the southernmost part of the country. Analyses of aerosol samples, precipitation, moss samples, and surface soils all demonstrate substantial contamination of southernmost Norway from long-range atmospheric transport. Moss biomonitoring at regular intervals since 1977 show substantially decreasing deposition over time for these metals, but levels in natural surface soils are still far above normal levels in the south. Concentrations of $\mathrm{Pb}$ in vascular plants have decreased at similar rates as shown in the moss, whereas $\mathrm{Zn}$ and $\mathrm{Cd}$ contents maintain a more constant level due to root uptake from the contaminated soil. Hg levels in moss and natural surface soil show little temporal and spatial variation, and may be mainly affected by net deposition of hemispheric $\mathrm{Hg}^{0}$.
\end{abstract}

Key words: Heavy metals, long-range transport, moss biomonitoring, surface soil, temporal trends.

\section{Introduction}

During the $1970 \mathrm{~s}$ it became evident that the southernmost part of the Scandinavian peninsula had been substantially polluted by atmospheric transport and deposition of heavy metals from source areas in other parts of Europe (Rühling and Tyler 1973, Steinnes 1980). Nationwide monitoring of atmospheric deposition of heavy metals in Norway started 1977 and has been continued at regular intervals (Steinnes et al. 2011). Precipitation in southern Norway exhibits strong enrichment of $\mathrm{Pb}, \mathrm{Zn}, \mathrm{As}, \mathrm{Cd}, \mathrm{Sb}, \mathrm{Mo}$, and $\mathrm{Bi}$ relative to major elements in the Earth's crust, demonstrating association with small aerosols (Berg et al., 1994). Detailed geographic surveys of natural surface soils and distribution in peat cores show that the main source of these elements is trans boundary pollution, and the same appear to be the case for V, Sn, and Tl. A survey of results from relevant studies prior to 2000 is available in the literature (Steinnes, 2001). This presentation is focusing on the long-time trends and evidence from more recent investigations.

\section{Monitoring of atmospheric deposition}

Following an introductory survey in 1977 the atmospheric deposition of heavy metals all ower Norway has been monitored every five years since 1985 using a network of 470 sampling sites for the terrestrial moss Hylocomium splendens (Steinnes et al. 2011a). Some typical results from time trend studies are shown in the case of $\mathrm{Pb}$ in Fig.1. In this case the 2010 deposition rate in the south, still mainly from transboundary pollution, is only about $5 \%$ of the 1977 figure. Substantial reduction is also seen for As, whereas the levels for $\mathrm{Cd}, \mathrm{Sb}$, and $\mathrm{V}$ are of the order $10-20 \%$ of those in 1977 . In the case of $\mathrm{Ni}$ and $\mathrm{Cu}$, which are less typical of long-range atmospheric transport, there is much less change in the south. In the far north-east there is very high deposition locally of these two metals due to emissions from Russian smelters situated close to the Norwegian border. This contribution has increased regularly over the time period concerned. In the case of $\mathrm{Hg}$ there is little geographical variation in moss over the country (Berg et al. 2003), presumably due to a geographically uniform contribution from the hemispheric pool of $\mathrm{Hg}^{0}$. 
Table 1. Mean values of $\mathrm{Pb}, \mathrm{Zn}$, and $\mathrm{Cd}$ in birch leaves and pine needles (ppm) at sites in southern and central Norway at three different times over a period of 19 years.

\begin{tabular}{|c|c|c|c|c|c|c|c|}
\hline \multicolumn{2}{|c|}{} & \multicolumn{3}{|c|}{ Birch leaves } & \multicolumn{3}{c|}{} \\
\cline { 3 - 8 } \multicolumn{2}{|c|}{} & & & & & \multicolumn{2}{c|}{ Pine needles } \\
\hline \multirow{3}{*}{ Southern N } & & 1982 & 1992 & 2001 & 1982 & 1992 & 2001 \\
& $\mathrm{~Pb}$ & 12.0 & 4.2 & 1.9 & 4.0 & 1.12 & 0.56 \\
& $\mathrm{Zn}$ & 291 & 243 & 253 & 55 & 61 & 68 \\
& $\mathrm{Cd}$ & 0.30 & 0.36 & 0.28 & 0.49 & 0.38 & 0.24 \\
\hline \multirow{3}{*}{ Central N. } & & & & & & & \\
& $\mathrm{Pb}$ & 0.37 & 0.28 & 0.03 & 0.81 & 0.21 & 0.08 \\
& $\mathrm{Zn}$ & 102 & 76 & 124 & 35 & 38 & 37 \\
& $\mathrm{Cd}$ & 0.07 & 0.06 & 0.08 & 0.02 & 0.01 & 0.02 \\
\hline
\end{tabular}
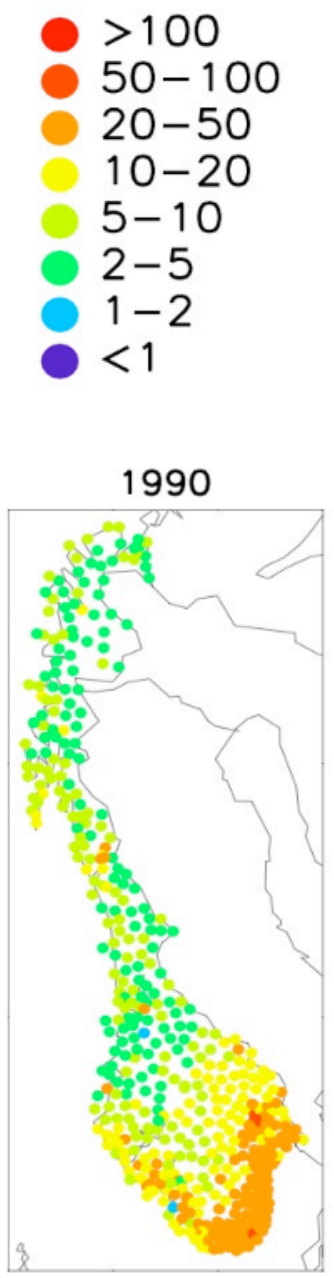
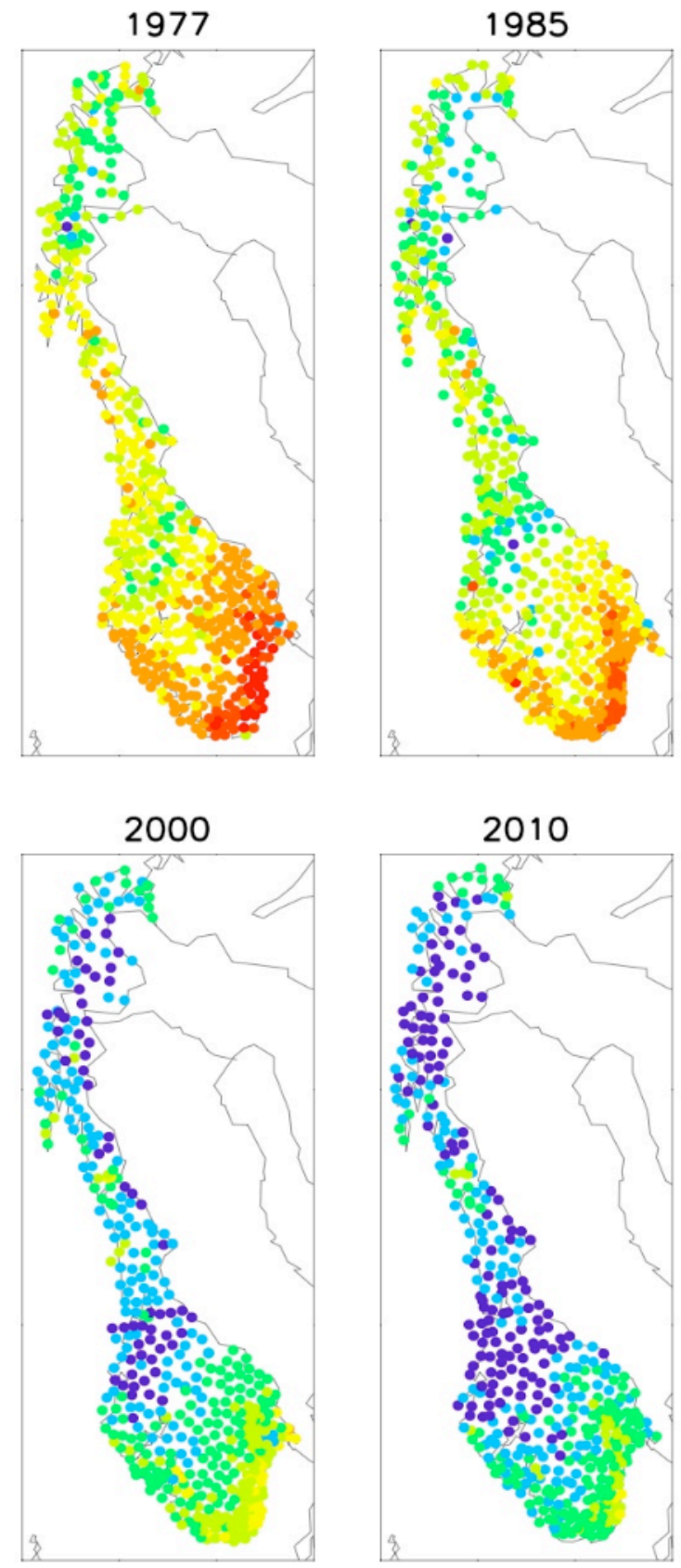

Fig. 1. Temporal and spatial trends of $\mathrm{Pb}$ deposition in Norway as illustrated by concentrations in moss samples (ppm). The same concentration scale applies to all maps. Reproduced from Steinnes et al. (2011b). 


\section{Surface contamination of natural soils}

Early studies of metals in the humus layer of natural soils showed concentrations of $\mathrm{Pb}$ about tenfold higher in the far south than in areas of central and northern Norway with low impact of trans boundary pollution. Significant but somewhat smaller enrichment in the south was shown for $\mathrm{Zn}, \mathrm{Cd}, \mathrm{Sb}$, and As. Results from repeated soil surveys carried out in 1995 (Nygård et al. 2012) and 2005 (E. Steinnes, unpublished results) confirm the geographical differences, but show some decrease of $\mathrm{Pb}$ in the south. A study of stable $\mathrm{Pb}$ isotopes in soil profiles (Steinnes et al. 2005) indicated that even in areas in the north, having receiving moderate to low $\mathrm{Pb}$ deposition, as much as $80-90 \%$ of the present surface soil $\mathrm{Pb}$ may be of pollution origin.

\section{Contamination of vascular plants}

Major components of the natural vegetation such as Birch (Betula pubescens) and Scots Pine (Pinus sylvestris) also show regional differences in heavy metal contents corresponding to the observed differences in atmospheric deposition. As demonstrated in Table 1 the $\mathrm{Pb}$ content in birch leaves and pine needles exhibits similar temporal and spatial trends as observed in moss, indicating that the atmosphere is the predominant source of $\mathrm{Pb}$ in the vegetation, and that root uptake from the contaminated soil is minimal. In the case of $\mathrm{Zn}$ and $\mathrm{Cd}$ the contents are also substantially higher in the south than in the central part of the country. These elements however show insignificant decrease in the plants with time in both regions, because they are readily taken up from the surface soil. Their levels continue to stay higher in plants in the south where the surface soil is still substantially polluted.

\section{Conclusion}

Deposition of heavy metals in Norway from long-range atmospheric transport has been followed by moss biomonitoring over a period of 35 years. For elements such as $\mathrm{Pb}, \mathrm{Zn}, \mathrm{Cd}, \mathrm{As}, \mathrm{Sb}, \mathrm{V}$, and $\mathrm{Sn}$ this has been a dominant source of supply to the natural environment. For most elements characteristic of this transport the supply has been substantially reduced over time, but the surface soil in the south remains considerably polluted, and the same applies to the vegetation in the case of metals readily supplied from the surface soil by root uptake.

\section{Acknowledgement}

Financial support was obtained from the Norwegian Climate and Pollution Agency to the moss surveys 1977-2010.

\section{References}

Steinnes E., Sjøbakk T.E., Donisa C., Brännvall ML. Quantification of pollutant lead inforest soils. Soil Sci Soc Amer Proc 2005; 69:1399-1404.

Nygård, T., Steinnes E., Røyset O. Distribution of 32 elements in organic surface soils. Contributions from atmospheric transport of pollutants and natural sources. Water Air Soil Pollut 2012; 223: 699-713.

Rühling $\AA$, Tyler G. Heavy metal deposition in Scandinavia. Water, Air, Soil Pollut 1973; 2: 445-455.

Steinnes E. Atmospheric deposition of heavy metals in Norway studied by analysis of moss samples using neutron activation analysis and atomic absorption spectrometry. J Radioanal Chem 1980; 58: 387-391.

Steinnes E. Metal contamination of the natural environment in Norway from long range atmospheric transport. Water, Air, Soil Pollut, Focus 2001; 1: 449-460.

Steinnes E, Berg T, Sjøbakk T.E. Temporal and spatial trends in $\mathrm{Hg}$ deposition monitored by moss analysis. Sci Total Environ 2003; 304: 215-219.

Steinnes E, Berg T., Uggerud H.T. Three decades of atmospheric metal deposition in Norway as evident from analysis of moss samples. Sci Total Environ 2011a; 412-413: 351-358.

Steinnes E, Berg T., Uggerud H.T., Pfaffhuber K.A. Atmospheric deposition of heavy metals in Norway. Nationwide survey 2010. State Program for Pollution Monitoring, 2011b: Report 1110, 40 pp (In Norwegian).

Steinnes E., Sjøbakk T.E., Donisa C., Brännvall M.L. Quantification of pollutant lead in forest soils. Soil Sci Soc Amer J 2005; 69: 1399-1404. 